Pak. j. sci. ind. res. Ser. B: biol. sci. 201154 (2) 64-70

\title{
An Integrated Nutrient Management Approach for Improving Maize (Zea mays L.) Yield
}

\author{
Naveed Iqbal, Asghar Ali, Muahammad Ather Nadeem, Muhammad Waseem*, \\ Muhammad Tahir, Muhammad Shahid Ibni Zamir and Asif Iqbal \\ Department of Agronomy, University of Agriculture, Faisalabad, 38040, Pakistan
}

(received May 10, 2010; revised September 8, 2010; accepted September 16, 2010)

\begin{abstract}
The study of integrated use of chemical fertiliser and compost showed beneficial effects on growth and yield of maize. Plant height, number of grain rows per cob, number of grains per row, number of grains per cob and 1000-grain weight were significantly affected by all the treatments. However, grain yield, biological yield, harvest index and grain-pith ratio were significantly affected by compost and chemical fertiliser alone or in certain combinations. The highest grain yield of $7.18 \mathrm{t} / \mathrm{ha}$ was obtained with the application of $25 \%$ nitrogen from compost $+75 \%$ nitrogen from chemical fertiliser.
\end{abstract}

Keywords: maize, compost, chemical fertiliser

\section{Introduction}

Maize is grown in Pakistan on an area of 1,026 thousands hectares with the production of 3.313 million tones and average grain yield of $3264 \mathrm{~kg} / \mathrm{ha}$ (GOP, 2008). The area under maize cultivation occupies the third position after wheat and rice, 98\% of which is grown in province of Punjab and Khyber Pukhtoon-khuwa. Basically it is a tropical plant but at present it is extensively cultivated world wide in subtropical and temperate regions. In some areas, it can be successfully cultivated twice a year as spring crop or autumn crop. Maize has wider adaptability on global basis as its cultivation expands from $50^{\circ} \mathrm{N}$ to $40^{\circ} \mathrm{S}$ latitude and an altitude of 3,300 meter (Martin et al., 1976).

Maize grain has high nutritional value as it contains $72 \%$ starch, $10 \%$ proteins, $4.8 \%$ oil, $8.5 \%$ fiber, $3 \%$ sugar and $1.7 \%$ ash (Chaudhry, 1983). However, in Pakistan its grain yield per unit area is low as compared to the potential of the cultivars being used. The main constraints in maize productivity are suboptimal plant density, inadequate supply of nutrition such as nitrogen, inadequate water supply, weed infestation, insect pest attack, etc.

In Pakistan, soil is generally low in organic matter; on an average, most of soils contain less than $1 \%$ organic matter. The arid climate results in rapid decomposition of organic matter, leaving very little in the soil for plants. Soil fertility can be increased through the

*Author for correspondence; E-mail: waseem_1028@yahoo.com utilisation of mineral as well as organic materials (Bashir and Bentel, 2001; Azad and Yousaf, 1982).

Crop residue and soil organic matter both can affect the diversity of soil microbial community and increase the crop yield (Bending et al., 2002). In the early years of development of chemical fertilisers, they were used as effective substitutes for the organic manure and a ready source of nutrients. Since, continuous use of chemical fertilisers creates potential polluting effect in the environment (Oad et al., 2004). Worldwide, there is now growing interest in the revival of use of organic manure for soil fertility. Economic premiums for certified organic grains have been driving many transition decisions related to the organic farming (Delate and Cambardella, 2004).

Integrated use of organic wastes and chemical fertilisers is beneficial in improving crop yield, soil $\mathrm{pH}$, organic carbon and available N, P and K in sandy loam soil (Rautaray et al., 2003).

Organic fertilisers including farmyard manure, poultry manure and compost may also be used for the crop production as a substitute of the chemical fertilisers. Synthesis of chemical fertilisers consumes a large amount of energy and money. Organic farming with or without chemical fertilisers seems to be possible solution for these situations (Prabu et al., 2003). The integration of organic sources and synthetic sources of nutrients not only supply essential nutrients but also have some positive interaction with chemical fertilisers to increase 
their efficiency and thereby reduce environmental hazards (Ahmad et al., 1996).

The use of organic manure is not a complete substitute to chemical fertiliser but in fact, it is an added dimension to organic farming and can play a vital role in optimising the best soil use, crop management and conservation. Keeping this objective in view, the present study was conducted to evaluate the potential of integrated nutrient management through compost and chemical fertiliser for improving yield of maize under the climatic conditions prevailing in Faisalabad, Pakistan.

\section{Materials and Methods}

The experiment was conducted at Agronomic Research Area, University of Agriculture, Faisalabad, Pakistan laid out in randomized complete block design (RCBD) with four replications having six treatments i.e. $\mathrm{T}_{1}$ (control), $\mathrm{T}_{2}$ (chemical fertiliser @ 250-120$125 \mathrm{NPK} \mathrm{kg} / \mathrm{ha}$ ), $\mathrm{T}_{3}$ (compost alone @ $10 \mathrm{t} / \mathrm{ha}$ ), $\mathrm{T}_{4}(25 \%$ nitrogen from compost $+75 \%$ nitrogen from chemical fertiliser), $\mathrm{T}_{5}(50 \%$ nitrogen from compost $+50 \%$ nitrogen from chemical fertiliser) and $\mathrm{T}_{6}(75 \%$ nitrogen from compost $+25 \%$ nitrogen from chemical fertiliser). The maize hybrid DEKALB 5219 was sown on a well prepared seed bed on $18^{\text {th }}$ August, 2008 in rows $75 \mathrm{~cm}$ apart with the help of a hand dibbler. Plant to plant distance of $20 \mathrm{~cm}$ was maintained at the time of sowing and later on through thinning the crop at 3 to 4 leaf stage. Recommended seed rate of $30 \mathrm{~kg} / \mathrm{ha}$ was used ( $66770 \mathrm{plant} / \mathrm{ha})$. Soil samples were collected with hand auger and analyzed. Nitrogen, phosphorus and potassium were applied (a) 250,120 and $125 \mathrm{~kg} / \mathrm{ha}$, respectively. The prepared compost was obtained from Lahore Compost (Pvt.) Ltd. and analysed chemically for its nutrients. The required amounts of compost per treatment were collected on these bases as shown in Table 1.

Compost was incorporated into the soil at the time of soil preparation. Nitrogen was applied in two doses i.e., half at sowing and remaining half was top dressed with the $2^{\text {nd }}$ irrigation; the remaining irrigation was applied according to the requirement. Entire amount of phosphorus and potassium was applied at the time of sowing. All other agronomic practices except those under study were kept normal and uniform for all the treatments. Soil fertility was determined in the sample taken before sowing the crop at the Soil Chemical Laboratories of Ayub Agriculture Research Institute, Faisalabad (Table 2).
Table 1. Composition of compost used

\begin{tabular}{ll}
\hline \hline Nutrient & $\begin{array}{l}\text { Composition } \\
(\% \text { dry matter })\end{array}$ \\
\hline Nitrogen & 2.5 \\
Phosphorus & 1 \\
Potassium & 1 \\
Organic matter & 50 \\
\hline \hline
\end{tabular}

The parameters recorded included plant height at maturity, number of grain rows per cob, number of grains per row, number of grains per cob, 1000 grain weight, biological yield, grain yield, grain pith ratio and harvest index. The data were analyzed statistically using Fisher's analysis of variance; individual treatment means were separated by using least significant difference (LSD) test at 5 percent probability level (Steel et al., 1997).

Table 2. Chemical analysis of air dried soil

\begin{tabular}{ll}
\hline \hline Determination & Value obtained \\
\hline $\mathrm{pH}$ & 7.9 \\
Organic matter & $0.65 \%$ \\
Available P & $7.3 \mathrm{ppm}$ \\
Available K & $197 \mathrm{ppm}$ \\
Total N & $0.08 \%$ \\
\hline \hline
\end{tabular}

\section{Results and Discussion}

Plant height at maturity. Plant height reflects not only the vegetative behaviour of the plant in response to applied inputs but also its productive efficiency in terms of crop yield. The plant height at maturity was the lowest $(154.7 \mathrm{~cm})$ in control treatment $T_{1}$, where, no fertilizer or compost was added (Fig.1). It was statistically similar to $T_{3}(160.6 \mathrm{~cm})$, where compost alone $(10 \mathrm{t} / \mathrm{ha})$ was applied. Maximum plant height $(197.5 \mathrm{~cm})$ was recorded in $\mathrm{T}_{2}$, where recommended dose of chemical fertiliser (250-120-125 NPK kg/ha) was added. It was followed by $\mathrm{T}_{4}$ where $191.6 \mathrm{~cm}$ plant height was recorded by adding $25 \%$ nitrogen from compost and $75 \%$ nitrogen from the chemical fertiliser; $\mathrm{T}_{5}$ yielded the plant height of $184.7 \mathrm{~cm}$ as the result of application of $50 \%$ nitrogen from compost $+50 \%$ nitrogen from chemical fertiliser and $\mathrm{T}_{6}$ yielded plant height of $173.9 \mathrm{~cm}$ on supplying $75 \%$ nitrogen from the compost and $25 \%$ nitrogen from the chemical fertiliser. Maximum plant height was achieved by $\mathrm{T}_{2}$, where recommended dose of chemical fertiliser was 


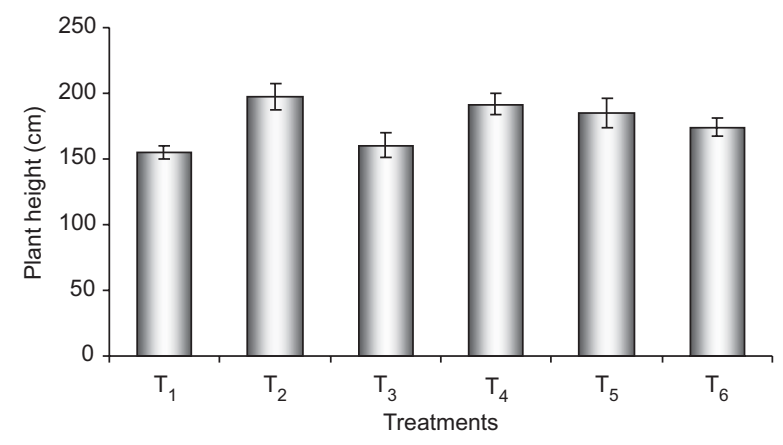

Fig. 1. Effect of integrated nutrient management on plant height at maturity.

applied; it might be due to the quick availability of nitrogen to the plants which enhanced their growth. Minimum plant height in control treatment $\left(\mathrm{T}_{1}\right)$ with no compost or fertiliser was attributed to less nutrient availability. These results are in agreement with the findings of Matheus (2004).

Number of grain rows per cob. Number of grain rows per cob is a key factor in determining the yield of maize crop. Number of grain rows per cob was significantly affected by different levels of compost and chemical fertiliser (Fig. 2). The comparison of treatment means shows that generally the compost and chemical fertiliser applications, either alone or in different combinations, produced higher number of grain rows per cob. Maximum number of grain rows per cob was recorded in treatment $\mathrm{T}_{5}$, where $50 \%$ nitrogen from compost $+50 \%$ nitrogen from chemical fertiliser were applied. The next higher value was obtained by treatment $\mathrm{T}_{4}(25 \%$ nitrogen from compost $+75 \%$ nitrogen from chemical fertiliser). It was followed by the treatment $\mathrm{T}_{2}$, where only the recommended dose of chemical was applied. It was statistically similar to treatment $\mathrm{T}_{6}$, where $75 \%$ nitrogen from compost and $25 \%$ nitrogen from the chemical fertiliser was supplied and this treatment is similar to

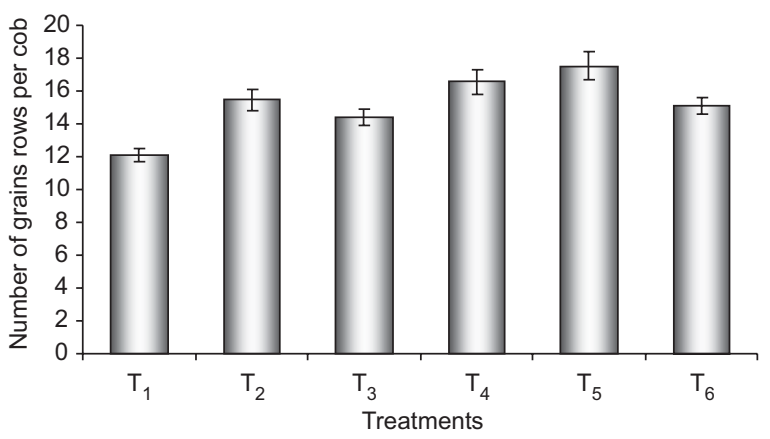

Fig. 2. Effect of integrated nutrient management on number of grain rows per cob.
$\mathrm{T}_{3}$, where compost alone (10 t/ha) was used.The minimum number of grain rows per cob was recorded in case of control treatment $\mathrm{T}_{1}$ in which no compost or chemical fertiliser was applied. The increased number of grain rows per cob in treatment $\mathrm{T}_{5}$, where $50 \%$ nitrogen from compost $+50 \%$ nitrogen from chemical fertiliser was applied might be attributed to better plant development through efficient utilisation of nitrogen by the plant due to the combined effect of the compost and the chemical fertiliser. These results are similar to those reported by Jayaprakash et al. (2004) who reported that number of grain rows per cob was significantly affected by the combined use of organic and inorganic fertilisers.

Number of grains per row. Number of grains per row is considered an important parameter that directly contributes to the yield of maize crop. It is mainly defined by the genetic make up of the plant but is also altered by the growing conditions like availability of nutrients, soil, climate etc., to some extent. The number of grains per row was significantly affected by integrated nutrient management (Fig. 3). Comparison of treatment means shows that compost and chemical fertiliser applications either alone or in different combinations produced higher number of grains per row than that of the control. Maximum number of grains per row was obtained by treatment $\mathrm{T}_{4}$, where $25 \%$ nitrogen from compost $+75 \%$ nitrogen from chemical fertiliser were applied. It was statistically similar with $\mathrm{T}_{5},(50 \%$ nitrogen from compost $+50 \%$ nitrogen from chemical fertiliser) followed by $T_{2}, T_{6}$ and $T_{3}$ in order. Minimum number of grains per row was recorded in the case of control treatment where no compost or chemical fertiliser was applied. Maximum number of grains per row by treatment $\mathrm{T}_{4}$ might be due to proper and timely availability of nutrient resulting in better growth as the

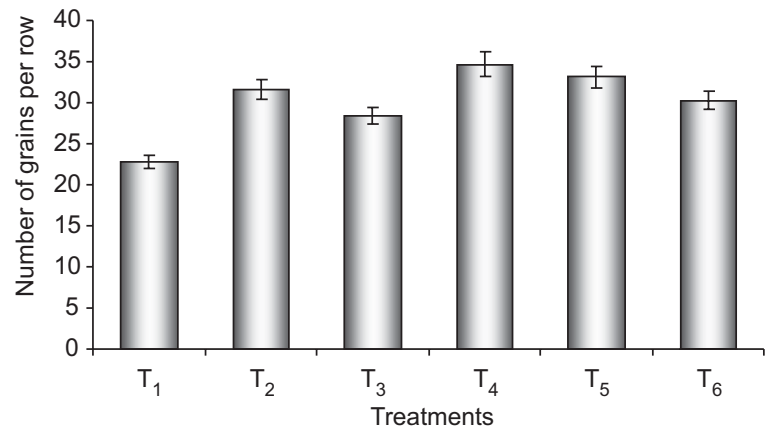

Fig. 3. Effect of integrated nutrient management on number of grains per row. 
compost enhanced the chemical fertiliser efficiency, while, in case of control treatment $T_{1}$ the minimum number of grains per row was due to the reduced growth resulting from poor nutrient availability. These results are same as were reported by Jayaprakash et al. (2004), Wang et al. (2003) and Liang et al. (1992).

Number of grains per cob. This is considered the main parameter directly contributing to the yield of maize crop. The more the number of grains per cob, the more will be the yield. The analysis of variance shows that the compost and the chemical fertiliser had significant affect on the number of grains per cob comparison of treatment means shows that generally the compost and the chemical fertiliser, applications either alone or in different combinations, produced higher number of grains per cob than that of the control (Fig. 4). Maximum number of grains per cob was recorded in treatment $\mathrm{T}_{5}$ ( $50 \%$ nitrogen from the compost $+50 \%$ nitrogen from chemical fertilizser). This increase in the number of grains per cob might be due to availability of nitrogen at proper time, which is required for better growth and development of plants and improvement in moisture retention and soil structure by the compost. It is statistically similar to treatment $\mathrm{T}_{4}(25 \%$ nitrogen from compost $+75 \%$ nitrogen from chemical fertiliser) which produced 531.3 grains per cob. It was followed by the treatments $\mathrm{T}_{2}$ producing 476.0 grains per cob through the use of recommended dose of chemical fertiliser (250-120-125 NPK kg/ha) and $\mathrm{T}_{6}$ yielding 426.3 grains per cob by adding $75 \%$ nitrogen from the compost and $25 \%$ nitrogen from the chemical fertiliser. Minimum number of grains per cob (354.8) was recorded in case of the control treatment, where no organic or inorganic fertilisers were used. It was statistically similar to treatment $\mathrm{T}_{3}$, where compost ( $10 \mathrm{t} / \mathrm{ha}$ ) was used. The minimum number of grains per cob might be the result

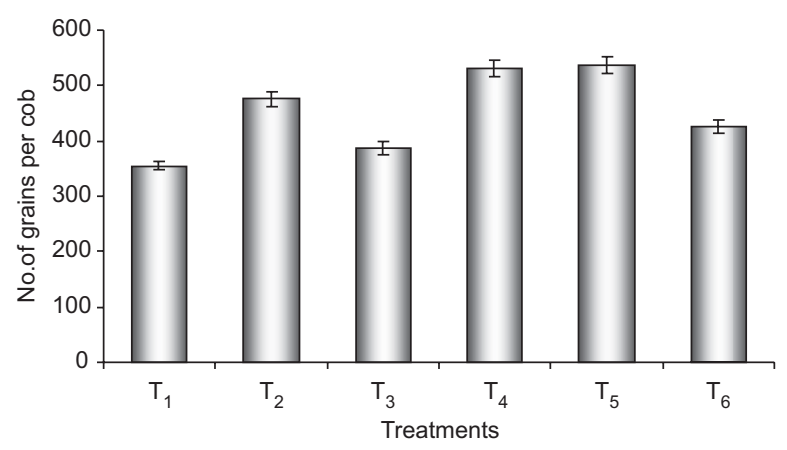

Fig. 4. Effect of integrated nutrient management on number of grains per cob. of of insufficiency of nutrients. Similar findings were given by Kumar et al. (2002); Schindler and Knighton (1999); Chaudhry et al. (1998); and Iqbal (1997).

1000-Grain weight (g). Among various parameters contributing to the economic yield of a crop, 1000-grain weight is of prime importance. It directly relates to the yield of the crop. Any variation in 1000-grain weight will affect the grain yield. The results show that integrated nutrient management affected the 1000-grain weight in highly significant way (Fig. 5). Maximum 1000 -grain weight was recorded by treatment $\mathrm{T}(25 \%$ nitrogen from compost $+75 \%$ nitrogen from chemical fertiliser) which was statistically similar to treatment $\mathrm{T}_{5}(50 \%$ nitrogen from compost $+50 \%$ nitrogen from chemical fertiliser). The reason might be that the proper dose of chemical fertiliser in combination with the compost increased the efficiency of chemical fertiliser which resulted in better growth and improvement in grain size and ultimately 1000 -grain weight was increased. Next was the treatments $T_{2}$ with the recommended dose of chemical fertiliser (250-120-125 NPK kg/ha). $\mathrm{T}_{6}(75 \%$ nitrogen from compost $+25 \%$ nitrogen from chemical fertiliser) and $\mathrm{T}_{3}$, where compost (10 t/ha) was applied.The minimum 1000-grain weight $\left(227.5 \mathrm{~g}\right.$ ) was recorded in case of control treatment $\left(\mathrm{T}_{1}\right)$ in which no compost or chemical fertiliser was added. The decrease in 1000-grain weight might be attributed to deficiency of nutrients throughout the plant life especially at the time of flowering and seed setting. Similar results were reported by Mahmoud (2006), Sharif et al. (2004) and Toor (1990), who found that combined application of organic and inorganic fertilisers significantly affected 1000 -grain weight.

Biological yield (t/ha). Biological yield reflects total biomass obtained by the plant during the life cycle in

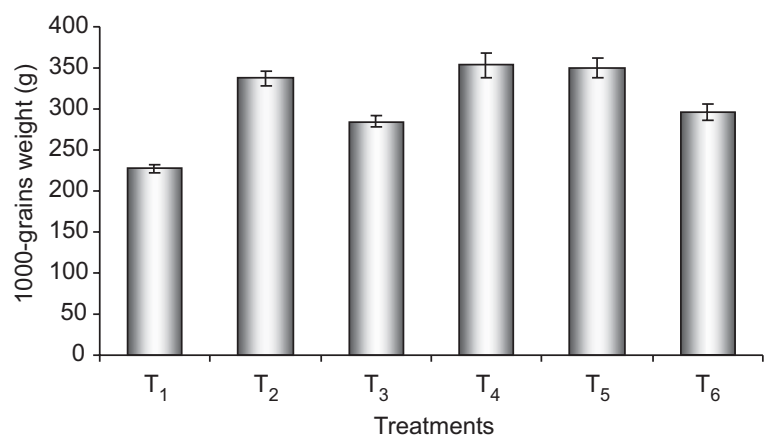

Fig. 5. Effect of integrated nutrient management on 1000 grains weight. 
the prevailing conditions (using different treatments); it comprises of three components, stalk, pith yield and grain yield (Fig.6). Integrated nutrient management was found to affect significantly the biological weight of maize plant at harvest. The significantly highest biological yield (16.86 $\mathrm{t} / \mathrm{ha}$ ) was achieved by $\mathrm{T}_{5}$ with $50 \%$ nitrogen from compost $+50 \%$ nitrogen from chemical fertiliser. Statistically non-significant difference was recorded by treatments $\mathrm{T}_{4}(16.34 \mathrm{t} / \mathrm{ha})$ and $\mathrm{T}_{2}(16.18$ t $/$ ha), where $25 \%$ nitrogen from compost $+75 \%$ nitrogen from chemical fertiliser and recommended dose of chemical fertiliser (250-120-125 NPK kg/ha) were applied, respectively. These were followed by the treatments $\mathrm{T}_{6}(15.46 \mathrm{t} / \mathrm{ha})(75 \%$ nitrogen from compost $+25 \%$ nitrogen from chemical fertiliser $)$ and $\mathrm{T}_{3}(14.40$ $\mathrm{t} / \mathrm{ha}$ ) in which compost (10 t/ha) was applied. The minimum dry matter $(9.748 \mathrm{t} / \mathrm{ha}$ ) was obtained in case of control treatment $\left(\mathrm{T}_{1}\right)$, where no organic inorganic fertiliser was applied.

The highest biological yield recorded in case of the treatment $\left(\mathrm{T}_{5}\right)$ might be attributed to more nutrient availability during the life cycle of the plant for its proper growth and development resulting in healthy plants and ultimately higher biological yield. The lowest biological yield by the control treatment may be due to the suppressed growth and development of plant as the result of nutrient deficiency. These results are confirmatory to those of Reddy et al. (2005) and Arshad et al. (2004), who noted increase in the biological yield through combined use of organic and inorganic fertilisers.

Grain yield (t/ha). Grain yield, also known as economic yield, is the most important plant parameter, being the end product of a grain crop. It is influenced by a combination of internal (genetic) factors. It is a function of an interaction among various yield determining

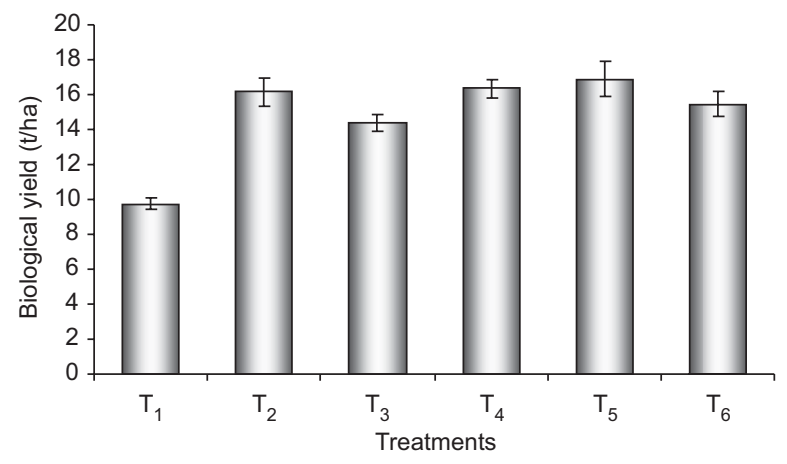

Fig. 6. Effect of integrated nutrient management on biological yield. components namely the number of cobs per plants, cob length, number of grains per cob and 1000-grain weight which show variations under the prevailing growing conditions and various crop management practices. Here, it was noted that the integrated nutrient management had a highly significant effect on grain yield (Fig. 7).

The maximum grain yield (7.182 $\mathrm{t} / \mathrm{ha}$ ) was recorded in case of the treatment $\mathrm{T}_{4}$, where $25 \%$ nitrogen from compost $+75 \%$ nitrogen from chemical fertiliser was applied. This better grain yield was attributed to the greater cob length and 1000-grain weight and increase in moisture retention and microbial activity by the compost. It was followed by the treatments $\mathrm{T}_{5}(6.923$ $\mathrm{t} / \mathrm{ha}), \mathrm{T}_{2}(6.595 \mathrm{t} / \mathrm{ha}), \mathrm{T}_{6}(5.872 \mathrm{t} / \mathrm{ha})$ and $\mathrm{T}_{3}(5.370 \mathrm{t} /$ ha). The minimum grain yield (3.352 t/ha) was recorded through the control treatment $\left(\mathrm{T}_{1}\right)$, where no compost or chemical fertiliser was applied. Reduction in yield might be due to the nutritional imbalance and deficiency of certain important plant growth elements at various important growth stages like flowering, seed formation and seed maturity. These results are similar to the findings of Ahmad et al. (2007), Laddha et al. (2006) and Nagassa et al. (2005).

Grain pith ratio. The data pertaining to the grain pith ratio (Fig. 8) showed that all the treatments affected grain pith ratio significantly except the control treatment. The maximum grain pith ratio (4.467) was recorded in case of treatment $\mathrm{T}_{5}(50 \%$ nitrogen from compost + $50 \%$ nitrogen from chemical fertiliser). Statistically non-significant difference was observed in case of treatments $\mathrm{T}_{4}(25 \%$ nitrogen from compost $+75 \%$ nitrogen from chemical fertiliser) and $\mathrm{T}_{2}$ (recommended dose of chemical fertiliser i.e., 250-120-125 NPK kg/ha). The treatments $\mathrm{T}_{6}$ and $\mathrm{T}_{3}$ were also statistically similar.

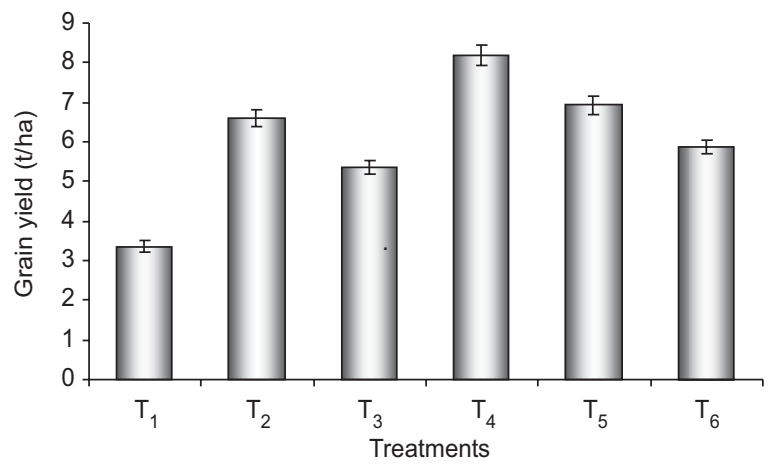

Fig. 7. Effect of integrated nutrient management on grain yield. 


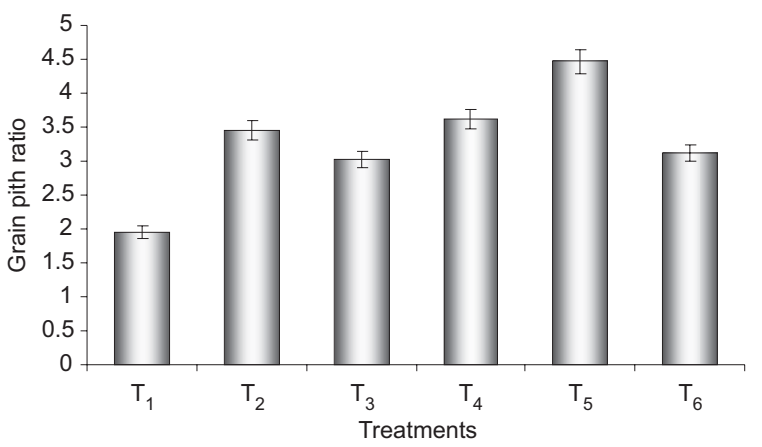

Fig. 8. Effect of integrated nutrient management on grain pith ratio.

The minimum grain pith ratio (1.955) was recorded in case of control treatment, where no nutrients were supplied through organic and inorganic fertilisers. The maximum grain pith ratio from the treatment $T_{5}$ might be attributed to the combined effect of compost and chemical fertiliser in proper ratio which enhanced reproductive growth as the result of high nutrient uptake. The minimum grain pith ratio (1.955), in case of the control treatment $T_{1}$, was due to nutrient deficiency which suppressed vegetative and reproductive growth. These results are similar to the findings of Nagassa et al. (2005) and McGonigle and Beauchamp (2004).

Harvest index (\%). The harvest index is a measure of productive efficiency i.e. how efficiently a crop can use its physiological inheritance. This determines the amount of photosynthates being transformed to the economic part of the plant. It is the ratio of economical yield over biological yield and is expressed in percentage (\%).

The data (Fig. 9) shows that all the treatments of compost and chemical fertiliser, either alone or in different combinations, significantly affected the harvest index. The maximum harvest index $(45.51 \%)$ was recorded in case of treatment $\mathrm{T}_{4}(25 \%$ nitrogen from compost +

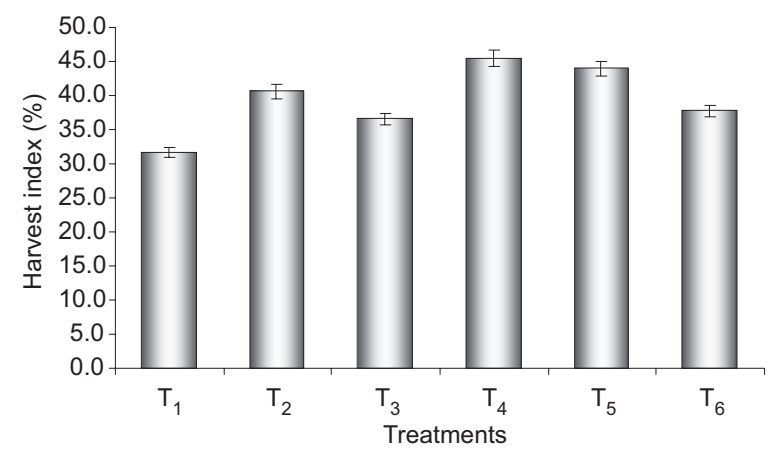

Fig. 9. Effect of integrated nutrient management on the harvest index.
$75 \%$ nitrogen from chemical fertiliser). It might be due to the timely availability of nutrients and increase in water holding capacity by the use of the compost. It was statistically similar to treatment $T_{5}(43.97 \%)$ in which $50 \%$ nitrogen from compost $+50 \%$ nitrogen from chemical fertiliser was applied. The minimum harvest index (31.63\%) was recorded in case of control treatment, where no compost or chemical fertiliser was applied. These results are confirmatory to those of Castho (1990).

\section{Conclusion}

It is concluded that plant height, number of grain rows per cob, number of grains per row, number of grains per cob and 1000-grain weight, grain yield, biological yield, harvest index and grain-pith ratio are significantly affected by all the treatments. The highest grain yield of $8.18 \mathrm{t} /$ ha was obtained with the application of $25 \%$ nitrogen from the compost $+75 \%$ nitrogen from the chemical fertiliser.

\section{References}

Ahmad, R., Shahzad, S.M., Khalid, A., Arshad, M., Mahmood, M.H. 2007. Growth and yield response of wheat (Triticum aestivum L.) and maize (Zea mays L.) to nitrogen and L-tryptophan enriched compost. Pakistan Journal of Botany, 39: 541-549.

Ahmad, N., Rashid, M., Vaes, A.G. 1996. Fertilisers and Their Uses in Pakistan, pp. 142-149; 172-175, National Fertiliser Development Centre (NFDC), Islamabad, Pakistan.

Arshad, M., Khalid, A., Mahmood, M.H., Zahir, Z.A. 2004. Potential of nitrogen and L-tryptophan enriched compost for improving growth and yield of hybrid maize. Pakistan Journal of Agricultural Sciences, 41: 16-24.

Azad, M.I., Yousaf, M.V. 1982. Recycling of organic matter to improve the soil productivity. Pakistan Journal of Agricultural Research, 22: 15-18.

Bashir, E., Bantel., R. 2001. Soil organic matter. In: Soil Science, pp. 235-250, National Book Foundation, Islamabad, Pakistan.

Bending, G.D., Turner, M.K., Jones, J.E. 2002. Interaction between crop residues and soil organic matter, quality and functional diversity of soil microbial communities. Soil Biology and Biochemistry, 34: 1073-1082.

Castho, P. 1990. Effect of NPK fertilisation and split application of $\mathrm{N}$ on lodging due to wind storm and 
harvestable grain yield of maize. Acta Agronomica Hungarica, 40: 281-294.

Chaudhry, M.A., Shafiq, M., Rehman, A. 1998. Effect of organic and inorganic fertiliser on maize crop response under eroded loess soil. Pakistan Journal of Soil Science, 15: 39-43.

Chaudhry, A.R. 1983. Maize in Pakistan, pp. 85-86, Agriculture Research Coordination Board, University of Agriculture, Faisalabad, Pakistan.

Delate, K., Cambardella, C.A. 2004. Agroecosystem performance during transition to certified organic grain production. Agronomy Journal, 96: 1288-1298.

GOP. 2008. Government of Pakistan. Economy Survey of Pakistan 2007-2008, Finance Division, Economic Advisor's Wing, Islamabad, Pakistan, (www. Accountancy. com.pk.).

Iqbal, M. 1997. Growth and Yield Response of Hybrid Maize to Nitrogen Application. M.Sc. (Hons.) Thesis, University of Agriculture, Faisalabad, Pakistan.

Jayaprakash, T.C., Nagalikar, V. P., Pujari, B.T., Setty, R.A. 2004. Effect of organics and inorganics on yield soil properties and available nutrient status of soil after harvest of maize crop under irrigation. Karnataka Journal of Agricultural Sciences, 17: 311-314.

Kumar, A., Thakur, K.S., Manuja, S. 2002. Effect of fertility levels on promising hybrid maize (Zea mays) under rainfed conditions of Himachal Pradesh. Indian Journal of Agronomy, 47: 526-530.

Laddha, K.C., Sharma, R.K., Sharma, S.K., Jain, P. M. 2006. Integrated nitrogen management in maize and its residual effect on black gram under dry land conditions. Indian Journal of Dry Land Agricultural Research and Development, 21: 177-184.

Liang, B.C., Mackenzie, A.F., Remillard, M. 1992. Effect of hybrid population densities, fertilisation and irrigation on grain corn. Canadian Journal of Plant Science, 27: 1163-1170.

Mahmoud, M.R. 2006. Residual effects of compost and biofertilisers on maize yield and some soil properties. Assiut Journal of Agricultural Sciences, 37: 185-200.

Martin, J.H., Leonard, W.H., Stamp, D.L. 1976. Principles of Field Crop Production, pp. 360-363, Macmillan Publishing Co. Inc., New York, USA.

Matheus, J.E.L. 2004. Agronomic evaluation of the use of compost waste of the sugar industry (Biofertilisers) in the cultivation of corn (Zea mays L.). Bioagro, 16: 219-224.
McGonigle,T.R., Beauchamp, E.G. 2004. Relation of yield of corn (Zea mays L.) to nitrogen in shoot and soil during the early-season following manure application to field plots. Canadian Journal of Soil Science, 84: 481- 490.

Nagassa, W., Heluf, G., Abdena, D., Geremew, E. 2005. Effect of integrated use of FYM, N and P fertilisers on maize in Western Oromia of Ethiopia. Indian Journal of Fertiliser, 1: 47-53.

Oad, F.C., Buriro, U.A., Agha, S.K. 2004. Effect of organic and inorganic fertiliser application on fodder maize production. Asian Journal of Plant Science, 3: 375-377.

Prabu, T., Narwadkar, P.R., Sanindranath, A.K., Rafi, M. 2003. Effect of integrated nutrient management on growth and yield of okra (Abelmoscchus esculentus L.) cv. Parbhani Kranti. Orissa Journal of Horticulture, 31: 17-21.

Rautaray, S.K., Ghosh, B.C., Mittra, B. N. 2003. Effect of fly ash, organic wastes and chemical fertiliser on yield, nutrient uptake, heavy metal content and residual fertility in a rice-mustard cropping sequence under acid lateritic soils. Bioresource Technology, 90: 275-283.

Reddy, S.S., Reddy, V.C., Ananda, M.C., Sivaraj, B. 2005. Direct effect of fertilisers and residual effect of organic manure on yield and nutrient uptake of maize (Zea mays L.) in groundnut-maize cropping system. Crop Research, 29: 390-395.

Schindler, F.V., Knighton, R.E.1999. Fate of fertiliser nitrogen applied to corn as estimated by isotropic and difference methods. Soil Science Society of America Journal, 63:1734-1740.

Sharif, M., Ahmed, M., Sharir, M.S., Khattak, R.A. 2004. Effect of organic and inorganic fertilisers on the yield and yield components of maize. Pakistan Journal of Agricultural Engineering and Veterinary Science, 20: 11-16.

Steel, R.G.D., Torrie, J.H., Dicky, D.A. 1997. Principles and Procedures of Statistics, A Biometrical Approach, pp. 352-358, $3^{\text {rd }}$ edition, McGraw Hill, Book Co. Inc., New York, USA.

Toor, S.A. 1990. Effect of NPK Application on the Growth and Yield of New Maize Genotype Planted in Two Geometrical Patterns. M.Sc. (Hons.). Thesis, University of Agriculture, Faisalabad, Pakistan.

Wang, W.B., Cai, D.X., Zhang, J.Q., Gao, X.K. 2003. Nitrogen uptake by corn and nitrogen recovery in grain in dry matter farm land. Chinese Agricultural Sciences, 2: 898-905. 